\title{
Sustainability Reporting: The Moderating Role of Audit Committee on Financial Performance
}

\author{
Dewi Ari Ani ${ }^{*}$, Diannita Kusumaningrum², Arda Raditya Tantra ${ }^{3}$ \\ 1, 2, 3 Ngudi Waluyo University \\ 1'dewiari@unw.ac.id \\ ${ }^{*} P$ enulis korespondensi
}

\begin{abstract}
Sustainability reporting is a tool for companies to communicate the efforts and results they make in managing themselves based on their environment, social and economy. This study examines financial factors affecting the level of sustainability reporting disclosure moderated by audit committee activity. The samples used were go-public companies listed in SRI-KEHATI index in 2019, and the ones participated in the Sustainability Award organized by NCSR in 2019 and published the 2018 sustainability reporting. The results confirm that firm size does not affect the level of sustainability reporting disclosure, while both liquidity and profitability variable affect. The frequency of audit committee meetings fails to moderate the relationship between firm size and the level of sustainability reporting disclosure, but is able to moderate both of the relationships between liquidity and profitability with the level of sustainability reporting disclosure. This result is expected to provide benefits for academics in developing researches on sustainability reporting.
\end{abstract}

Keywords: Sustainability reporting, audit committee, firm size, liquidity, profitability

\begin{abstract}
Abstrak
Sustainability reporting merupakan sarana bagi perusahaan untuk mengomunikasikan usaha dan hasil yang dilakukan perusahaan dalam mengelola perusahaan berdasarkan lingkungan, sosial dan ekonomi. Penelitian ini menguji faktor keuangan yang berpengaruh pada tingkat pengungkapan sustainability reporting yang dimoderasi oleh aktivitas komite audit. Sampel yang digunakan adalah perusahaan go public yang masuk dalam indeks Sri-Kehati tahun 2019 dan perusahaan go public di Indonesia yang menjadi peserta Sutainability Award 2019 yang diselenggarakan oleh NCSR dan menerbitkan sustainability reporting 2018. Hasil penelitian ini adalah ukuran perusahaan tidak mempengaruhi tingkat pengungkapan sustainability reporting. Sebaliknya variabel likuiditas dan profitabilitas berpengaruh pada tingkat pengungkapan sustainability reporting. Frekuensi rapat komite audit tidak mampu memoderasi hubungan antara ukuran perusahaan dengan tingkat pengungkapan sustainability reporting namun mampu memoderasi hubungan antara likuiditas dengan tingkat pengungkapan sustainability reporting dan profitabilitas dengan tingkat pengungkapan sustainability reporting. Hasil penelitian ini diharapkan bermanfaat bagi akademisi dalam mengembangkan penelitian sustainability reporting.
\end{abstract}

Kata Kunci: Sustainability reporting, komite audit, ukuran perusahaan, likuiditas, profitabilitas 


\section{INTRODUCTION}

There are many challenges for companies in this $21^{\text {st }}$ century, such as pollution, scarcity of natural resources and various negative impacts of company operations for current and future generations. Its drive various professional organizations to take action by implementing non-financial information. Sustainability reporting is a report that presents a lot of non-financial information based on three basic aspects (triple bottom line): economic, environmental and social aspect. By using GRI guidelines, the organizations or companies can report both positive and negative impacts of company operations on the economy, environment and society. This report reveals more information needed by stakeholders (Ioana \& Andriana, 2013).

Lako (2018) stated that the sustainability reporting is specially designed for companies to provide complete, balanced, comparable, timely, clear and reliable material information. Its implications for managing the economic, financial information or non-financial information to achieve sustainable goals. With these benefits, the companies adopting the sustainability reporting are expected to be able to provide information needed by the stakeholders so that they can make both financial and non-financial decisions accurately. Researches on sustainability reporting have been widely examined. Several experts analyzed the extent of disclosure of economic, social and environmental information (Ameer \& Othman, 2012; Aniktia \& Khafid, 2015; Ching et al., 2014, 2016; Gavana et al., 2017; Kurniawan et al., 2018; Manes-Rossi et al., 2018; Siew et al., 2013; van Der Esch \& Steurer, 2014). Besides, some also analyzed the extent of social and environmental information disclosure without disclosing the economic information (Alazzani et al., 2017; Fernandez-Feijoo et al., 2014; Fuente et al., 2016). However, there are also several researchers who only analyzed the environmental information disclosure (Ben-Amar et al., 2017; Faisal et al., 2018; Liao et al., 2015).

Several other studies link the sustainability reporting to the board of directors (Al-Shaer \& Zaman, 2016; Ben-Amar et al., 2017; Fernandez-Feijoo et al., 2014; Janggu et al., 2014; Jizi, 2017), audit committee (Ahmed Haji, 2015; Aniktia \& Khafid, 2015; Chariri et al., 2018) and financial performance (Ameer \& Othman, 2012; Aniktia \& Khafid, 2015; Faisal et al., 2018; Siew et al., 2013). Further, studies on the relationship between financial performance and non-financial information disclosure including the sustainability reporting information have also been done. Ameer \& Othman (2012) studied the relationship between sales growth, ROA, profit before tax/PBT, cash flow on operating with sustainability reporting on global corporation and found that the financial variables had positively affected the extent of information disclosure in the sustainability reporting. Furthermore, Chikwendu et al. (2016) had also previously examined the impact of sustainability reporting on the financial performance of companies on Nigerian Stock Exchange and found that the sustainability reporting information positively related to return on asset. In addition, Aniktia \& Khafid (2015) examined the effect of financial performance on profitability proxies and found that it did not affect the extent of information disclosure in sustainability reporting, although leverage positively affected it.

Meanwhile, studies on the audit committee role in encouraging the disclosure of non-financial information including the one in sustainability reporting have been carried 
out by several researchers. Othman et al. (2014) studied companies on Malaysia Stock Exchange and found that the audit committee was independent and their activities had no influence on the extent of voluntary information disclosure. A study by Ahmed Haji (2015) on companies in Malaysia revealed that the size of audit committee positively related to the disclosure of non-financial information (such as intellectual capital), while the independent audit committee had no effect on the intellectual capital information. Aniktia \& Khafid (2015) examined companies on Indonesia Stock Exchange and found that number of audit committee meetings had a positive influence on the extent of information disclosure in the sustainability reporting. Most of previous studies focus on the direct effect of the relationship between audit committee and the extent of non-financial information disclosure, including the information on sustainability reporting.

The research gap in this study uses the audit committee activity as a moderating variable on the relationship between financial performance and the extent of information in sustainability reporting. The majority studies examined the direct effect of the relationship between the audit committe activity and the extent of disclosure of non-financial information including information on sustainability reporting (Ahmed Haji, 2015; Ameer \& Othman, 2012 ; Aniktia \& Khafid, 2015; Chariri et al., 2018). This study uses the audit committee activity as a moderating variable on the relationship between financial performance and the extent of information in sustainability reporting, based on the previous research results which resulted in an insignificant relationship between the audit committee meetings and non-financial information disclosure ( Othman et al., 2014). However, other studies found the opposite (Ahmed Haji, 2015; Aniktia \& Khafid, 2015; Chariri et al., 2018)with a focus on intellectual capital (IC. Therefore, based on these differences, it possible for the audit committee activity as a moderating variable on the relationship between financial performance and the extent of information in sustainability reporting. Further, through the audit committee meetings discussing the financial reports and performance, they can provide input to the board of commissioners on matters related to the financial reports and performance. Thus, the board of commissioners may also deliver the input to the board of directors to be disclosed in the firm reports. This study use financial performance is represented by firm size, liquidity and profitability.

Frias-Aceituno et al. (2014) claimed that big companies need more external sources of funding through bank and capital market thus big companies must disclose more information as accountability to public, creditor and investor. Clayton et al. (2015) also supported that big companies tend to have great pressure in providing transparent, complete, timely, relevant and understandable information. Therefore, they tend to provide more information to public to gain legitimacy. Therefore, the first hypothesis that can be proposed is as follows:

$\mathbf{H}_{\mathbf{1}}$ : Firm size positively influences the extent of information disclosure on sustainability reporting.

Liquidity is one of indicators of financial performance. The higher liquidity is better the performance. This implies that the company is able to meet its short-term obligations 
to the third parties. Investors will choose to invest their capital in companies with a high liquidity because it indicates that they will not experience any financial difficulties in paying obligations in the short term. Similarly, creditors and suppliers will also be willing to be their business partners. These are all in line with the stakeholder theory. Deegan (2007) argued that the main stakeholder of a company may influence the company's strategies. It is because companies with a high liquidity tend to provide more information to emphasize that they are in a healthy condition (Daniel, 2013). Thus, the second hypothesis that can be proposed is as follows:

$\mathbf{H}_{2}$ : Liquidity positively influences the extent of information disclosure on sustainability reporting.

Profitability is measured by return on assets (ROA) it's refers to an indicator of investment quality. The higher the ROA, the higher the incentive to disclose information. This may result to reducing market risks. Similarly, the higher the voluntary information disclosure, the higher the ROA achieved by the company. A manager with a high profitability tends to use the information to get compensation for his performance (Frias-Aceituno et al. 2014). For these reasons, the third hypothesis that can be proposed is as follows:

$\mathbf{H}_{3}$ : Profitability positively influences the extent of information disclosure on sustainability reporting.

Aniktia \& Khafid, (2015) tested the effect of corporate governance and financial performance on the disclosure of information in sustainability reporting and confirmed that the audit committee activity and meeting frequency proxy had a positive effect on the extent of disclosure in sustainability reporting. Meanwhile, Kurniawan et al., (2018) had examined the effect of information disclosure in sustainability reporting on firm value in companies listed in Indonesia and Singapore Stock Exchange. They found that only the economic information which had effects on the firm value, while the environmental and social information did not. Further, other researchers had studied the influence of frequency of audit committee meetings on non-financial information disclosure and the results revealed that the frequency of audit committee meetings had a positive influence on the non-financial information disclosure (Allegrini \& Greco, 2013; Appuhami \& Tashakor, 2017; Chariri et al., 2018; Li et al., 2012). Similarly, through committee meetings, the audit committee may provide input on relevant information to the commissioners to be further delivered to the directors. Therefore, the information can be presented in the firm reports. For these reasons, the audit committee plays a role in providing input consisting information that explains the company's financial performance. However, the suggested information can be responded positively or negatively by the stakeholders. Thus, the audit committee may strengthen or weaken the company's information disclosure. The following are the fourth hypotheses that can be proposed:

$\mathbf{H}_{4 \mathbf{a}}$ : Frequency of audit committee meetings moderates the relationship between firm size and the extent of information on sustainability reporting. 
$\mathbf{H}_{4 \mathbf{b}}$ : Frequency of audit committee meetings moderates the relationship between liquidity and the extent of information on sustainability reporting.

$\mathbf{H}_{4 \mathbf{c}}$ : Frequency of audit committee meetings moderates the relationship between profitability and the extent of information on sustainability reporting.

\section{METHOD}

The population of this study were go-public companies listed in SRI-KEHATI index in 2019 and the ones listed in IDX that were also participants of Sustainability Award held by NCSR in 2019. The data was collected using a purposive sampling. From the two data sources, there were 42 companies but only 27 companies published the sustainability reporting in 2018. Researchers excluded 1 company because it had negative profits in 2018. Therefore, there was a total of 26 companies used as the research sample. The data used was secondary data in the form of sustainability reporting in 2018 to calculate the SR index and company annual reports to find data on firm size, liquidity, profitability and number of audit committee meetings in 1 year.

The following are operational variables used in this study:

1. Sustainability reporting

Sustainability reporting is measured by the $4^{\text {th }}$ generation of GRI index which consists of 91 indicators.

$$
S R=\frac{\text { Disclosure of } G R I-G 4}{91}
$$

2. Firm size

Researchers often use total assets to refer firm size (Brammer\& Pavelin 2008; Daniel 2013; Dong \& Stettler 2011; Kusuma 2011; Frias-Aceituno et al. 2014; Yuen et al. 2009). Big companies have greater pressure to provide complete information because they are more complex in terms of business activities and have more parties related to them. This study uses the natural logarithm of total assets as a proxy for firm size.

$$
\text { Size }=\text { Ln Asset }
$$

3. Liquidity

Liquidity refers to the ratio between current assets and current debt. This ratio shows the company's ability to meet short-term liabilities (Palepu et al., 2000). The company's inability to fulfill its short-term obligations will have an impact on the company's reputation. The loss of stakeholder trust (such as suppliers, creditors, investors) due to a bad liquidity can disrupt the company's activities. Simultaneously, it can reduce the company's chances of making a profit. In this study, the liquidity is measured using the following formula:

$$
\text { Liquid }=\frac{\text { Current Assets }}{\text { Current Liabilities }}
$$


4. Profitability

Profitability is a measure of a company's success in investing. A high rate of return indicates a good level of company's profitability. Profitability can be measured by ROA, ROE or net profit margin (Palepu et al., 2000). Companies with a high level of profitability will tend to provide a lot of information to obtain more capital at low costs and to maintain the stability of the company's position (Frias-Aceituno et al. 2014). To measure profitability using ROA, the following ratio is used:

$$
\text { Profit }=\frac{\text { Net Income }}{\text { Total Assets }}
$$

5. Audit Committee Activity

The audit committee plays a role in carrying out the supervisory function in financial reporting, so that they can provide input to the board of commissioners to advise the board of directors to present information that explains the condition of the company's performance, both good and poor performance. In line with the research conducted by Aniktia \& Khafid (2015), this study uses the number of audit committee meetings as a proxy for audit committee activity. This study uses the number of audit committee meetings as a moderating variable.

Meet $=$ number of audit committee meetings in 1 year

This study uses multiple regression analysis in Model 1 to test $H_{1}, H_{2}$ and $H_{3}$. Meanwhile, Model 2 uses multiple regression analysis to test $\mathrm{H}_{4 \mathrm{~A}^{\prime}}, \mathrm{H}_{4 \mathrm{~B}}$, and $\mathrm{H}_{4 \mathrm{C}}$. Model 1 examines the determinants of the level of sustainability reporting disclosure, whether the independent variables (including firm size, liquidity and profitability) have an effect on the level of sustainability reporting disclosure. On the other hand, Model 2 examines the moderating effect of the number of audit committee meetings on the relationship between financial performance (firm size, liquidity and profitability) and the level of sustainability reporting disclosure. The regression equation of Model 1 and Model 2 in this study are as follows:

SR $=\alpha+\beta_{1}$ Size $+\beta_{2}$ Liquid $+\beta_{3}$ Profit $+\beta_{4}$ Meet $+\mathrm{e}$

SR $=\alpha+\beta_{1}$ Size $+\beta_{2}$ Liquid $+\beta_{3}$ Profit $+\beta_{4}$ Meet $+\beta_{5}$ Size* Meet $+\beta_{6}$ Liquid* Meet + $\beta_{7}$ Profit* Meet + e

Note:

SR = level of sustainability reporting disclosure

$\alpha=$ constant

$\beta=$ regression coefficient

Size $=$ firm size

Liquid = liquidity

Profit $=$ profitability

Meet $=$ number of audit committee meetings in 1 year

$\mathrm{e}=$ error 


\section{RESULT AND DISCUSSION}

This study uses secondary data obtained from websites of the go-public companies listed in SRI-KEHATI index in 2019 and were participants of the Sustainability Reporting Award held by NCSR in 2019. Samples were taken from the two data sources that published sustainability reporting in 2018. This study uses a 90\% confidence level.

\section{Descriptive Statistics}

Descriptive statistics describe average value, lowest and highest value, and standard deviation of the processed data. The following table 1 displays the descriptive statistics:

Table 1 Descriptive Statistics

\begin{tabular}{lrrrrr} 
& N & Minimum & Maximum & \multicolumn{1}{c}{ Mean } & Std. Deviation \\
\hline SR & 26 & .0769 & .8901 & .451818 & .2467093 \\
Size & 26 & 21.93 & 32.45 & 26.3502 & 2.66882 \\
Liquid & 26 & .0600 & 4.2013 & 1.244032 & 1.1030896 \\
Profit & 26 & .0100 & .4808 & .072800 & .0955820 \\
Meet & 26 & 3.00 & 41.00 & 15.3462 & 10.51453 \\
Valid N (listwise) & & & & & \\
\hline
\end{tabular}

Source: processed data

Table 1 shows a total of 26 companies used as samples of this study. The minimum level of sustainability reporting disclosure is $7.69 \%$ and the maximum value is $89.01 \%$. The gap between the minimum and maximum value is large because companies that were in the financial and banking industry less disclosed their environmental information indicators. A standard deviation of 0.2467093 indicates that the gap between the sample value and the average level of sustainability reporting was relatively small. The firm size shows a minimum value of 21.93 , a maximum value of 32.45 , an average of 26.3502 , and a standard deviation of 2.6682. Meanwhile, liquidity has a minimum value of 0.060 , a maximum value of 4.2013, an average of 1.24402 and a standard deviation of 1.1030896 . This indicates that the gap between each sample and the sample mean was not too large. Further, profitability has a minimum value of 0.100 , a maximum value of 0.4808 , an average value of 0.072800 , and a standard deviation of 0.0955820 . A small standard deviation indicates that the profitability of the sample studied had a range of values that was almost the same as the average value of around $7 \%$. Meanwhile, the audit committee meeting frequency variable has a fairly large range with a minimum value of 3 , a maximum value of 41 , an average value of 15.3462 , and a standard deviation of 10.51453. A high value of standard deviation indicates that the gap between sample and the mean was quite large. This also shows that the number of audit committee meetings in the sample varied. 


\section{Result of Classical Assumption Test}

The data processed in this study has passed the classical assumption test which includes multicollinearity, normality and heteroscedasticity test. The results have met the required conditions.

\section{Hypothesis Testing}

This study uses a 90\% confidence level for both Model 1 and Model 2. The following are the results of hypothesis testing:

\section{Determination Coefficient Test $\left(\mathbf{R}^{2}\right)$}

Results of coefficient determination test for Model 1 and Model 2 are presented in the following table:

Table 2 Results of Determination Coefficient Test $\left(\mathbf{R}^{2}\right)$

\begin{tabular}{ccccc}
\hline Model & R & R-Square & Adjusted R-Square & Std. Error of Estimate \\
\hline 1 & .617 & .381 & .263 & .2117393 \\
2 & .729 & .532 & .350 & .198873 \\
\hline
\end{tabular}

Source: processed data

Table 2 shows that in Model 1, the value of Adjusted R-Square is 0.263 which indicates that the level of sustainability reporting disclosure is $26.3 \%$ and explained by firm size, liquidity, profitability and frequency of audit committee meetings. The remaining $73.7 \%$ is explained by other variables not included in this study. When the interaction of the audit committee meeting frequency is included along with firm size, liquidity and profitability in Model 2, the Adjusted R-Square increases to 0.350. This means that the independent variable and the interaction between the independent and the moderating variable can explain $35 \%$ of the level of sustainability reporting disclosure.

\section{F Test}

Results of $\mathrm{F}$ test for both Model 1 and Model 2 are presented in table as follows:

Table 3 Results of $F$ Test

\begin{tabular}{lccccc}
\hline \multicolumn{1}{c}{ Model } & Sum of Square & Df & Mean Square & F & Sig \\
\hline Model 1 & & & & & \\
Regression & 0.58 & 4 & 0.145 & 3.235 & 0.032 \\
Residual & 0.942 & 21 & 0.045 & & \\
Total & 1.522 & 25 & & & \\
\hline Model 2 & & & & & \\
Regression & 0.81 & 7 & 0.116 & 2.924 & 0.031 \\
Residual & 0.712 & 18 & 0.04 & & \\
Total & 1.552 & 25 & & & \\
\hline
\end{tabular}

Source: processed data 
Results of F test in table 3 show that Model 1 and Model 2 are significant, so that the two regression equations are suitable as a tool to analyze the simultaneous effect of firm size, liquidity and profitability on the level of sustainability reporting disclosure moderated by the frequency of audit committee meetings.

\section{3. $t$ Test}

Results of $\mathrm{t}$ test for Model 1 is presented as follows:

Table 4 Results of $t$ Test of Model 1

\begin{tabular}{cccc}
\hline Model & Variable & B & Sig. \\
\hline 1 & Constant & -0.413 & 0.429 \\
& Size & 0.018 & 0.322 \\
& Liquid & 0.082 & $0.075^{*}$ \\
& Profit & 1.345 & $0.013^{*}$ \\
& Meet & 0.013 & $0.012^{*}$ \\
\hline
\end{tabular}

Source: processed data

Based on the results of t test in table 4, a regression equation of Model 1 can be formulated as follows:

$$
\text { SR }=-0.413+0.018 \text { Size }+0.082 \text { Liquid }+1.345 \text { Profit }+0.013 \text { Meet }+\mathrm{e}
$$

Table 4 shows the results of $t$ test with a confidence level of $90 \%$. The $t$ test results of Model 1 show that the firm size does not affect the level of sustainability reporting disclosure, so that $\mathrm{H}_{1}$ is not supported empirically $(\mathrm{B}=0.018$, sig. $=0.322)$. The result contrary to the result of research by Mawarti \& Yulianti (2015) which showed a significant relationship between firm size and the level of sustainability reporting disclosure but the relation was negative. Another study examined the relationship between firm size and non-financial information (intellectual capital) produced a positive relationship (Ameer \& Othman, 2012) but the result of research conducted by Othman et al. (2014) showed insignificant. Table 4 show the sig. value of liquidity $(B=0.082$, sig. $=0.075)$ so $\mathrm{H}_{2}$ is accepted, liquidity has positive affect on the level of sustainability reporting disclosure. This result contrary to research conducted by Mawarti \& Yulianti (2015) which showed it was no significant. The result of t-test on profitability $(B==1.345$, sig. $=0.013)$, sig. value is less than $10 \%$, so that $\mathrm{H}_{3}$ can be supported empirically. This result consistent with research conducted by (Ahmed Haji, 2015; Ameer \& Othman, 2012; Mawarti \& Yulianti, 2015) which showed a positive relationship between profitability and non-financial information disclosure including sustainability reporting disclosure. Further, the Meet variable in Model 1 also shows a positive effect on the level of sustainability reporting disclosure $(\mathrm{B}=0.013$, sig. $=0.012)$. 
Results of $\mathrm{t}$ test for Model 2 is presented as follows:

Table 5 Results of $t$ Test of Model 2

\begin{tabular}{|c|c|c|c|}
\hline Model & Variable & B & Sig. \\
\hline \multirow[t]{8}{*}{2} & Constant & 0.033 & 0.976 \\
\hline & Size & 0.004 & 0.917 \\
\hline & Liquid & -0.026 & 0.756 \\
\hline & Profit & 2.895 & $0.011^{*}$ \\
\hline & Meet & -0.32 & 0.592 \\
\hline & Size*Meet & 0.002 & 0.455 \\
\hline & Liquid *Meet & 0.016 & $0.051^{*}$ \\
\hline & Profit*Meet & -0.361 & $0.068^{*}$ \\
\hline
\end{tabular}

Source: processed data

Based on the results of $t$ test in table 5, a regression equation of Model 2 can be formulated as follows:

$\mathrm{SR}=0.033+0.004$ Size -0.026 Liquid +2.895 Profit -032 Meet +0.002 Size*Meet +

0.016 Liquid*Meet -0.361 Profit*Meet + e

The $t$ test of Model 2 in table 5 also uses a 90\% confidence level. The results show that Size $(B=0.004$, sig. $=0.917)$ and Liquid $(B=-0.026$, sig. $=0.756)$ have no effect on the level of sustainability reporting disclosure. However, the profitability variable has an effect on the level of sustainability reporting disclosure with a significance of $1.1 \%$ and beta of 2.895 . The frequency of audit committee meetings fails to moderate the relationship between firm size and the level of sustainability reporting disclosure. Therefore, $\mathrm{H}_{4 \mathrm{a}}$ is not supported empirically $(\mathrm{B}=0.002$, sig. $=0.455)$. Conversely, the frequency of audit committee meetings is able to strengthen the relationship between liquidity and the level of sustainability reporting disclosure $(B=0.016$, sig. $=0.051$ ). However, it weakens the relationship between profitability and the level of sustainability reporting disclosure $(B=-0.361 .$, sig. $=0.068)$. Therefore, $H_{4 b}$ and $H_{4 c}$ are supported empirically. The moderation result of the frequency of audit committee meetings which weakens the relationship between profitability and sustainability reporting happened because profitability was considered crucial for the company. Thus, when the company experienced a sharp decline in profit, it was necessary to understand the cause, including the possibility of errors in accounting records, production errors, or other possible factors which resulted in holding many meetings to monitor the level of company profit. The decline in profit impacted CSR activities which were often manifested in the environmental care activities. Simultaneously, the decline in CSR activities resulted in decreasing the information disclosed in sustainability reporting. 


\section{CONCLUSIONS}

It can be concluded that the firm size variable does not affect the level of sustainability reporting disclosure. On the other hand, the liquidity and profitability variable have an effect on the level of sustainability reporting disclosure. The frequency of audit committee meetings is unable to moderate the relationship between firm size and the level of sustainability reporting disclosure, but it is able to strengthen the relationship between liquidity and the level of sustainability reporting disclosure and weaken the relationship between profitability and the level of sustainability reporting disclosure.

This research is expected to provide benefits for academics in developing researches on sustainability reporting. Future researches are suggested to examine other financial variables as independent variables and add more samples of go-public companies and those that are not.

\section{REFERENCES}

Ahmed Haji. (2015). The role of audit committee attributes in intellectual capital disclosures: Evidence from Malaysia. Managerial Auditing Journal, 30(8-9), 756-784. https://doi. org/10.1108/MAJ-07-2015-1221

Al-Shaer, H., \& Zaman, M. (2016). Board gender diversity and sustainability reporting quality. Journal of Contemporary Accounting and Economics, 12(3), 210-222. https:// doi.org/10.1016/j.jcae.2016.09.001

Alazzani, A., Hassanein, A., \& Aljanadi, Y. (2017). Impact of gender diversity on social and environmental performance: evidence from Malaysia. Corporate Governance (Bingley), 17(2), 266-283. https://doi.org/10.1108/CG-12-2015-0161

Allegrini, M., \& Greco, G. (2013). Corporate boards, audit committees and voluntary disclosure: Evidence from Italian Listed Companies. Journal of Management and Governance, 17(1), 187-216. https://doi.org/10.1007/s10997-011-9168-3

Ameer, R., \& Othman, R. (2012). Sustainability practices and corporate financial performance: A study based on the top global corporations. Journal of Business Ethics, 108(1), 61-79. https://doi.org/10.1007/s10551-011-1063-y

Aniktia, R., \& Khafid, M. (2015). Pengaruh Mekanisme Good Corporate Governance dan Kinerja Keuangan Terhadap Pengungkapan Sustainability Report. Accounting Analysis Journal, 4(3), 1-10. https://doi.org/10.15294/aaj.v4i3.8303

Appuhami, R., \& Tashakor, S. (2017). The Impact of Audit Committee Characteristics on CSR Disclosure: An Analysis of Australian Firms. Australian Accounting Review, 27(4), 400-420. https://doi.org/10.1111/auar.12170

Ben-Amar, W., Chang, M., \& Mcllkenny, P. (2017). Board Gender Diversity and Corporate Response to Sustainability Initiatives: Evidence from the Carbon Disclosure Project. Journal of Business Ethics, 142(2), 369-383. https://doi.org/10.1007/s10551-0152759-1 
Brammer, S., \& Pavelin, S. (2008). Factors influencing the quality of corporate environmental disclosure. Business Strategy and the Environment, 17(2), 120-136. https://doi. org/10.1002/bse.506

Chariri, A., Januarti, I., \& Yuyetta, E. N. A. (2018). Audit Committee Characteristics and Carbon Emission Disclosure. E3S Web of Conferences, 73, 1-5. https://doi.org/10.1051/ e3sconf/20187302001

Chikwendu, O., Okafar, G., \& Caleb D.A, J. (2016). Effect of Sustainability Reporting on Nigeria Listed Companies Performance. Canadian Contemporary, 1(1).

Ching, H. Y., Gerab, F., \& Toste, T. H. (2014). Scoring Sustainability Reports using GRI indicators: A Study based on ISE and FTSE4Good Price Indexes. Journal of Management Research, 6(3), 27. https://doi.org/10.5296/jmr.v6i3.5333

Ching, H. Y., Toste, T., \& Tardelli, R. (2016). A Reference Model of Sustainability Disclosure based on four Sustainability Stock Indexes. Journal of Management Research, 8(4), 44. https://doi.org/10.5296/jmr.v8i4.9786

Clayton, A. F., Rogerson, J. M., \& Rampedi, I. (2015). Integrated Reporting vs. Sustainability Reporting for Corporate Responsibility in South Africa. Bulletin of Geography SosioEconomic Series, 6(29), 7-17. https://doi.org/10.1108/AJEMS-11-2013-0102

Daniel, N. U. (2013). Pengaruh Ukuran Perusahaan, Leverage dan Likuiditas Terhadap Luas Pengungkapan Lapporan Keuangan (Studi Empiris pada Perusahaan yang Terdaftar di Bursa Efek Indonesia). Jurnal Akuntansi, 1(1).

Faisal, F., Andiningtyas, E. D., Achmad, T., Haryanto, H., \& Meiranto, W. (2018). The content and determinants of greenhouse gas emission disclosure: Evidence from Indonesian companies. Corporate Social Responsibility and Environmental Management, 25(6), 1397-1406. https://doi.org/10.1002/csr.1660

Fernandez-Feijoo, B., Romero, S., \& Ruiz-Blanco, S. (2014). Women on boards: Do they affect sustainability reporting? Corporate Social Responsibility and Environmental Management, 21(6), 351-364. https://doi.org/10.1002/csr.1329

Frias-Aceituno, J. V., Rodriquez-Ariza, L., \& Garcia-Sanchez, I. M. (2014). Explanatory Factors of Integrated Sustainability and Financial Reporting. Business Strategy and the Environment, 72(December 2012), 56-72. https://doi.org/10.1002/bse.1765

Fuente, J., Garcia-Sanchez, I. M., \& Lozano, M. . (2016). The role of the board of directors in adoptionGRI guidelines for disclosure of CSR information. Journal of Cleaner Production. https://doi.org/10.1016/j.jclepro.2016.09.155.This

Gavana, G., Gottardo, P., \& Moisello, A. M. (2017). Sustainability reporting in family firms: A panel data analysis. Sustainability (Switzerland), 9(1), 1-18. https://doi.org/10.3390/ su9010038

Ioana, D., \& Andriana, T. (2013). New Corporate Reporting Trends, Analysis on The Evolution of Integrated Reporting. Annals of the University of Oradea, Economic Science Series., 22(July), 1520-1524. 
Janggu, T., Darus, F., Zain, M. M., \& Sawani, Y. (2014). Does Good Corporate Governance Lead to Better Sustainability Reporting? An Analysis Using Structural Equation Modeling. Procedia - Social and Behavioral Sciences, 145, 138-145. https://doi.org/10.1016/j. sbspro.2014.06.020

Jizi, M. (2017). The Influence of Board Composition on Sustainable Development Disclosure. Business Strategy and the Environment, 26(5), 640-655. https://doi.org/10.1002/ bse.1943

Kurniawan, T., Sofyani, H., \& Rahmawati, E. (2018). Pengungkapan Sustainability Report dan Nilai Perusahan: Studi Empiris di Indonesia dan Singapura. Kompartemen: Jurnal Ilmiah Akuntansi, 16(1), 1-20. https://doi.org/10.30595/kompartemen.v16i1.2100

Kusuma, I. W. (2011). The impact of financial, non-financial, and corporate governance attributes on the practice of global reporting initiative (gri) based environmental disclosure. 13(2), 21-22.

Lako, A. (2018). Sustainability Reporting, Apa Manfaatnya? Fakultas Ekonomi Dan Bisnis Universitas Katolik Soegijapranata Semarang, December.

Li, J., Mangena, M., \& Pike, R. (2012). The effect of audit committee characteristics on intellectual capital disclosure. British Accounting Review, 44(2), 98-110. https://doi. org/10.1016/j.bar.2012.03.003

Liao, L., Luo, L., \& Tang, Q. (2015). Gender diversity, board independence, environmental committee and greenhouse gas disclosure. British Accounting Review, 47(4), 409-424. https://doi.org/10.1016/j.bar.2014.01.002

Manes-Rossi, F., Tiron-Tudor, A., Nicolò, G., \& Zanellato, G. (2018). Ensuring more sustainable reporting in europe using non-financial disclosure-de facto and de jure evidence. Sustainability (Switzerland), 10(4), 7-9. https://doi.org/10.3390/su10041162

Mawarti, C. P., \& Yulianti, Y. (2015). Analisis Pengungkapan Sustainability Report Pada Perusahaan Non-Keuangan Tahun 2009-2013. Jurnal Dinamika Akuntansi, 7(2), 167-181. ttps://doi.org/10.15294/jda.v7i2.4129

Othman, R., Ishak, I. F., Arif, S. M. M., \& Aris, N. A. (2014). Influence of Audit Committee Characteristics on Voluntary Ethics Disclosure. Procedia - Social and Behavioral Sciences, 145, 330-342. https://doi.org/10.1016/j.sbspro.2014.06.042

Palepu, K. G., Healy, P. M., Bernard, V. L., Wright, S., Bradbury, M., \& Lee, P. (2000). Business Analysis \& Valuation. Business, 957. http://books.google.com/books?

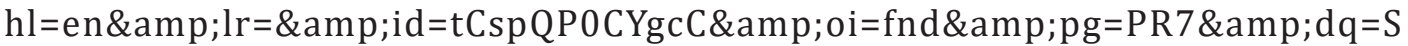
trategy+process,+cintent,+context+an+international+perspective\&amp;ots=-gMZvHbLMt\&amp;sig=vGe72LHzg4hofsDcvBGeWHr88RI

Siew, R. Y. J., Balatbat, M. C. A., \& Carmichael, D. G. (2013). The relationship between sustainability practices and financial performance of construction companies. Smart and Sustainable Built Environment, 2(1), 6-27. https://doi. org/10.1108/20466091311325827 
van Der Esch, S., \& Steurer, N. (2014). Comparing public and private sustainability monitoring and reporting. PBL Publication Number 1437, 1437, 40. http://www.pbl.nl/ en/publications/en/comparing-public-and-private-sustainability-monitoring-and-reporting

Yuen, C. Y., Liu, M., Zhang, X., \& Lyu, C. (2009). A Case Study of Voluntary Disclosure by Chinese Enterprises. Asian Journal of Finance \& Accounting, 1(2), 118-145. https:// doi.org/http://www.macrothink.org/journal/index.php/ajfa/issue/archive 